\title{
Exploration of Rhizosphere Associated Chromogenic Bacterial Strain - Staphylococcus aureus Strain BRTSI-1
}

\author{
P. Suwetha ${ }^{1}$, S. Shivaranjani ${ }^{1}$, M. Soundarya ${ }^{1}$, B. Santhiya ${ }^{1}$, V. Roja ${ }^{1}$, N. Aaliya \\ Mehnaaz $^{1}$, G. Vaishnavi ${ }^{1}$, G. Ramya ${ }^{2}$, A. Vidya ${ }^{1}$, A. Barathi ${ }^{1}$ and J. Hemapriya ${ }^{1 *}$ \\ ${ }^{1}$ D. K. M College for Women (Autonomous), Department of Microbiology, Vellore, \\ Tamil Nadu, India \\ ${ }^{2}$ Bioresource Technology Lab, Department of Biotechnology, Thiruvalluvar University, \\ Vellore, Tamil Nadu, India \\ *Corresponding author
}

A B S T R A C T

\begin{tabular}{|c|}
\hline Keywords \\
\hline $\begin{array}{l}\text { Arachis hypogaea, } \\
\text { Chromogenecity, } \\
\text { Pigments, Rhizosphere } \\
\text { Staphylococcus aureus }\end{array}$ \\
\hline Article Info \\
\hline $\begin{array}{l}\text { Accepted: } \\
25 \text { June } 2018 \\
\text { Available Online: } \\
10 \text { July } 2018\end{array}$ \\
\hline
\end{tabular}

Natural pigments were obtained and utilized from plants, insects and ores in prehistoric period and it has been over ruled by the synthetic dyes and pigments, inspite of its vast array of disadvantages to the ecosystem. The demand for natural pigments has triggered the researchers to look for an alternative approach, which could replace the synthetic pigments. Microorganisms such as algae, fungi, actinomycetes and bacteria play an interesting role in the world of colors with their chromogenecity. This study reports the isolation of chromogenic bacterial strain BRTSI-1 from the rhizosphere of Arachis hypogaea. The strain BRTSI-1 was identified as Staphylococcus aureus (NCBI accession number MH412806) based on their morphological, biochemical and 16S rDNA sequencing results. The culture condition for maximizing pigment production was found to be $30^{\circ} \mathrm{C}$ at neutral $\mathrm{pH}$. The methanolic extract of the pigment was spectroscopically analyzed using UV- Vis spectrophotometry between 400-600 nm. FTIR analysis explained the functional groups present in the methanolic extract.

\section{Introduction}

Ever since the prehistoric period, natural pigments were explored from plants, insects and ores and it has been over ruled by the emergence of synthetic dyes and pigments, inspite of its vast array of disadvantages to the ecosystem. Currently, Pigments produced from natural sources are regaining global interest and is gaining significance in order to combat the toxicity problem caused by the synthetic pigments (Kumar et al., 2015). The recent awareness in human safety and environmental conservation has also created fresh enthusiasm for natural sources of pigments. Compared to synthetic pigments, microbial pigments shows better biodegradability and higher compatibility with the environment, and have numerous applications from food to cosmetics. There have been increasing interest in the field of natural pigments because of their biological activities such as antioxidant property, antimicrobial property against pathogenic 
bacteria, fungi, virus and protozoa. Natural pigments are obtained from various sources such as plants, animals, algae and microbes which include bacteria and fungi. The natural pigments from plants have instability against light, heat or adverse $\mathrm{pH}$, low water solubility and are often not available throughout the year. Microorganisms can produce various pigments such as carotenoids, melanins, flavins, quinones, prodigiosins, monascins, violacein or indigo. Incubating temperature is the main factor which depends on the type of microorganism (Smitha et al., 2017). Among various microbes, bacteria are one of the most important candidates with abundance of biological properties. Exploration of secondary metabolites produced by bacteria can be readily accomplished because isolates may grow rapidly and produce high yields of the desired product using optimized culture conditions, lost cost substrate, independent from weather conditions, easy and faster growth (Luiza et al., 2018). The carotenoids are naturally occurring group of pigments that are widespread in bacteria, algae, and other eukaryotic organisms. These pigments have important functions in photosynthesis, nutrition, and protection against photooxidative damage (Kirsh et al., 2006; Choi et al., 2017).

In the present study, chromogenic bacterial strain was isolated from Rhizosphere of Arachis hypogaea. The bacterial isolate was characterized morphological, biochemical and $16 \mathrm{~S}$ rDNA sequencing. The pigment of the bacterial isolate was characterized by UVVisible spectrophotometry and FTIR analysis.

\section{Materials and Methods}

\section{Sample collection}

Soil zone found proximal to the plant roots of Arachis hypogaea were selected as the source for isolating bacterial strains. About $5 \mathrm{~g}$ of the soil samples were collected aseptically, in a sterile polythene bag and transported aseptically to Bioresource Technology Lab, Department of Biotechnology, Thiruvalluvar University, Serkkadu, Vellore, Tamil Nadu.

\section{Isolation of chromogenic bacterial strains}

Rhizosphere soil sample was serially diluted using autoclaved water and plated over the surface of Nutrient agar plates and were incubated for $24 \mathrm{~h}$ at $30{ }^{\circ} \mathrm{C}$. After incubation the plates were observed for the appearance of chromogenic bacterial colonies. Isolation procedure was carried out according to Ribeiro et al., (2012) with slight modification.

\section{Identification of BRTSI-1strain by $16 \mathrm{~S}$ rRNA sequencing}

Strain BRTSI-1 was subjected to standard morphological and biochemical characterization accordingly to Bergey's manual of systematic bacteriology. The isolate was also subjected for16S rDNA sequencing. The genomic DNA from the bacterial strain was isolated and $\sim 1.5 \mathrm{~kb}$ rDNA fragment was amplified using high fidelity PCR polymerase followed by bi-directional sequencing using forward, reverse and internal primers. The sequence data are further analyzed for its closest neighbors.

\section{Optimization of culture conditions}

Loopful culture of BRTSI-1 was inoculated in conical flasks containing $100 \mathrm{ml}$ of nutrient broth. All the flasks were incubated at different $\mathrm{pH}(4,5,6,7,8$ and 9) and different temperature ranges $(20,25,30,35,40,45$ and $50{ }^{\circ} \mathrm{C}$ ) and incubated for $24 \mathrm{~h}$. Following incubation, the bacterial growth was monitored in above mentioned flasks to check the optimum $\mathrm{pH}$ and temperature for maximizing bacterial biomass. The optimum culture conditions that exhibited maximum 
growth were observed and were maintained for further studies.

\section{Extraction of the pigment from BRTSI-1}

$10 \mathrm{ml}$ of overnight broth culture of BRTSI-1 was taken in a sterile centrifuge tube and centrifuged at $4000 \mathrm{rpm}$ for 15 mins in a cooling centrifuge. Supernatant was discarded, and $2 \mathrm{ml}$ of methanol was added to the pellet and mixed properly using a cyclomixer until the pigmented cells become colorless. The sample was centrifuged again at $4000 \mathrm{rpm}$ for 10 min to remove left out cell debris from the extracted pigment. Supernatant was transfered to fresh test tube (Prasad et al., 2013).

\section{Characterization of bacterial pigment}

\section{UV- VIS Spectrophotometry}

Methanolic extract of the bacterial pigment was subjected for Spectra analysis using UV visible spectrophotometer (Jasco V-730) in the range of 400-600 $\mathrm{nm}$ to find out the maximum absorption spectrum. Methanol was used as reference (Garg and Ram, 2017).

\section{FTIR analysis of bacterial pigment}

FTIR analysis was carried out to detect the presence of functional groups in the extracted pigment. For pigment analysis, FTIR was considered as a complementary technique that could provide the molecular and structural information of organic and inorganic molecules present in the pigment.

\section{Results and Discussion}

\section{Isolation and identification of Rhizosphere bacteria by $16 \mathrm{~S}$ r DNA Analysis}

Among various morphologically diverse strains, a single chromogenic- yellow color colony was selected and designated as BRTSI-
1 (Fig 1). The morphological and biochemical characteristics of the isolate BRTSI-1 is tabulated in Table 1. A total of 694 bases sequence of PCR amplified 16S r DNA gene was determined from the isolate BRTSI-1, which corresponds to more than $99 \%$ of the gene sequence. In the analysis at NCBI and RDP sites it showed homology to 16S r DNA sequences from Staphylococcus species. In the phylogenetic analysis, the sequence formed a cluster within Staphylococcus species with $100 \%$ boot strap value, confirming the identity of the isolate as strain of this species. The highest similarity value exists with Staphylococcus aureus (CP018629.1). The bacterial strain was identified as Staphylococcus aureus strain BRTSI-1 (Fig.2 \& 3). The sequence was submitted to GenBank with NCBI accession number MH412806.

\section{Biomass and pigment optimization: Influence of temperature and $\mathrm{pH}$}

Bacterial biomass and pigment production by Staphylococcus aureus strain BRTSI-1was proved to be temperature dependent. Bacterial biomass and pigment production gradually increased with increase in incubation temperature, reaching its maximum at $35^{\circ} \mathrm{C}$ and thereafter a steady decline was observed. (Fig. 4). Bacterial biomass and pigment production by Staphylococcus aureus strain BRTSI-1 gradually increased with increase in $\mathrm{pH}$ level, reaching its maximum at $\mathrm{pH} 7.0$ whereas, the bacterial growth was found to be reduced at extremes of $\mathrm{pH}$ (acidic and alkaline) (Fig. 5).

\section{Characterization of bacterial carotenoid}

\section{UV-VIS spectrophotometry of bacterial carotenoid}

Bacterial carotenoids are lipophilic in nature, which are soluble in organic solvents. 
Table.1 Morphological, Physiological and Biochemical Characteristics of strain BRTSI-1

\begin{tabular}{|c|c|c|}
\hline S. No & Test & Observations \\
\hline 1 & $\begin{array}{l}\text { Morphology } \\
\text { Grams staining } \\
\text { Cell shape and arrangement } \\
\text { Motility }\end{array}$ & $\begin{array}{l}\text { Positive } \\
\text { Cocci arranged in clusters } \\
\text { NonMotile }\end{array}$ \\
\hline 2 & $\begin{array}{l}\text { Colony Characters on Nutrient agar } \\
\text { Colony morphology } \\
\text { Colony size } \\
\text { Colony elevation } \\
\text { Colony edge } \\
\text { Pigmentation }\end{array}$ & $\begin{array}{l}\text { Round } \\
2-3 \mathrm{~mm} \\
\text { Raised } \\
\text { Entire } \\
\text { chromogenic (yellow) }\end{array}$ \\
\hline 3 & $\begin{array}{l}\text { Sugar Fermentation } \\
\text { Lactose } \\
\text { Maltose } \\
\text { Sucrose }\end{array}$ & $\begin{array}{l}\text { Positive -Acid } \\
\text { Positive-Acid } \\
\text { Positive-Acid }\end{array}$ \\
\hline 4 & $\begin{array}{l}\text { Enzyme Reaction } \\
\text { Urease Production } \\
\text { Nitrate Reductase } \\
\text { Oxidase } \\
\text { Coagulase } \\
\text { Catalase Activity }\end{array}$ & $\begin{array}{l}\text { Negative } \\
\text { Positive } \\
\text { Negative } \\
\text { Positive } \\
\text { Positive }\end{array}$ \\
\hline 5 & $\mathrm{H}_{2} \mathrm{~S}$ Production & Positive \\
\hline 6 & Gelatin & Positive (24 h) \\
\hline
\end{tabular}

Fig.1 Chromogenic Bacterial strain BRTSI-1 grown in Nutrient Agar plate

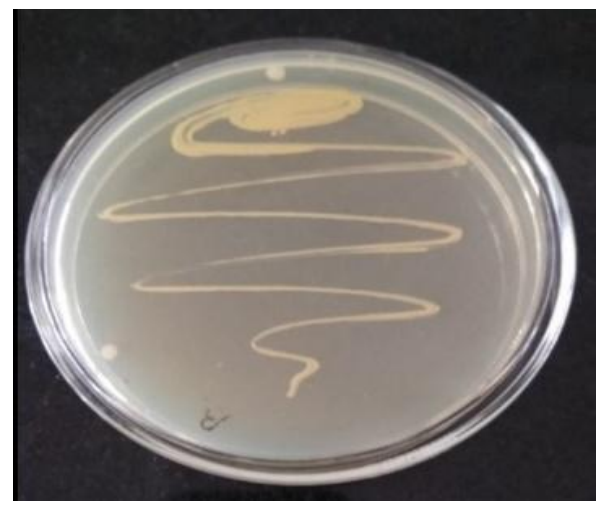

Fig.2 PCR amplified 16S r RNA sequence of Chromogenic Bacterial strain BRTSI-1

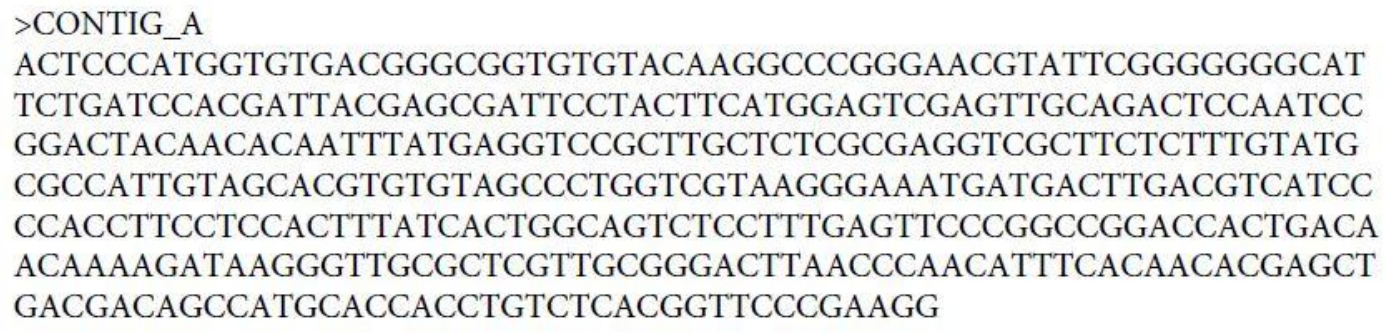


Fig.3 Phylogenetic tree of the strain BRTSI-1

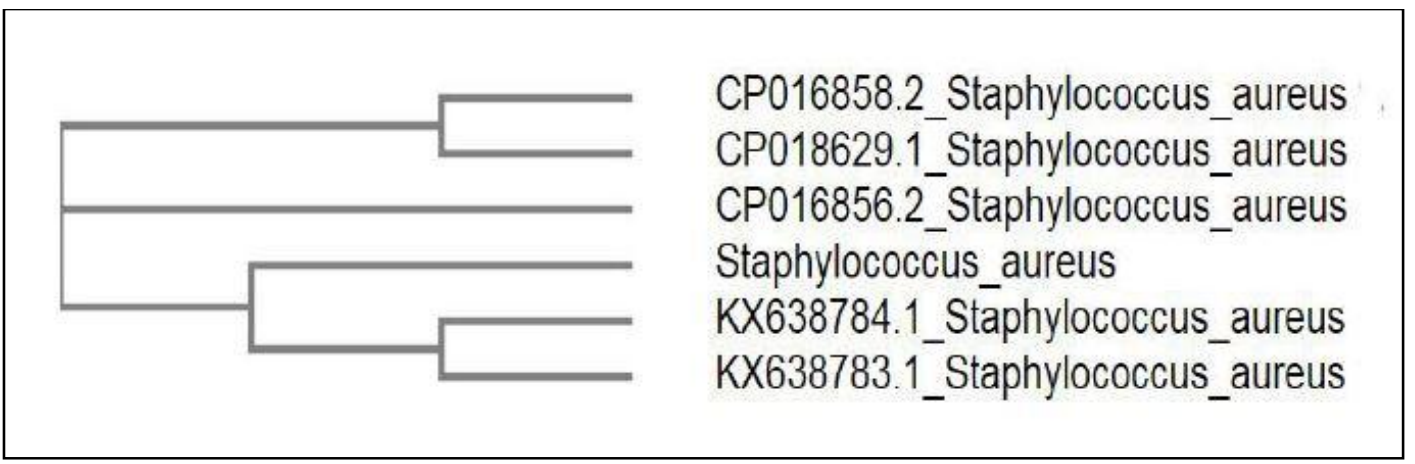

Fig.4 Effect of Temperature on the biomass of Staphylococcus aureus strain BRTSI-1

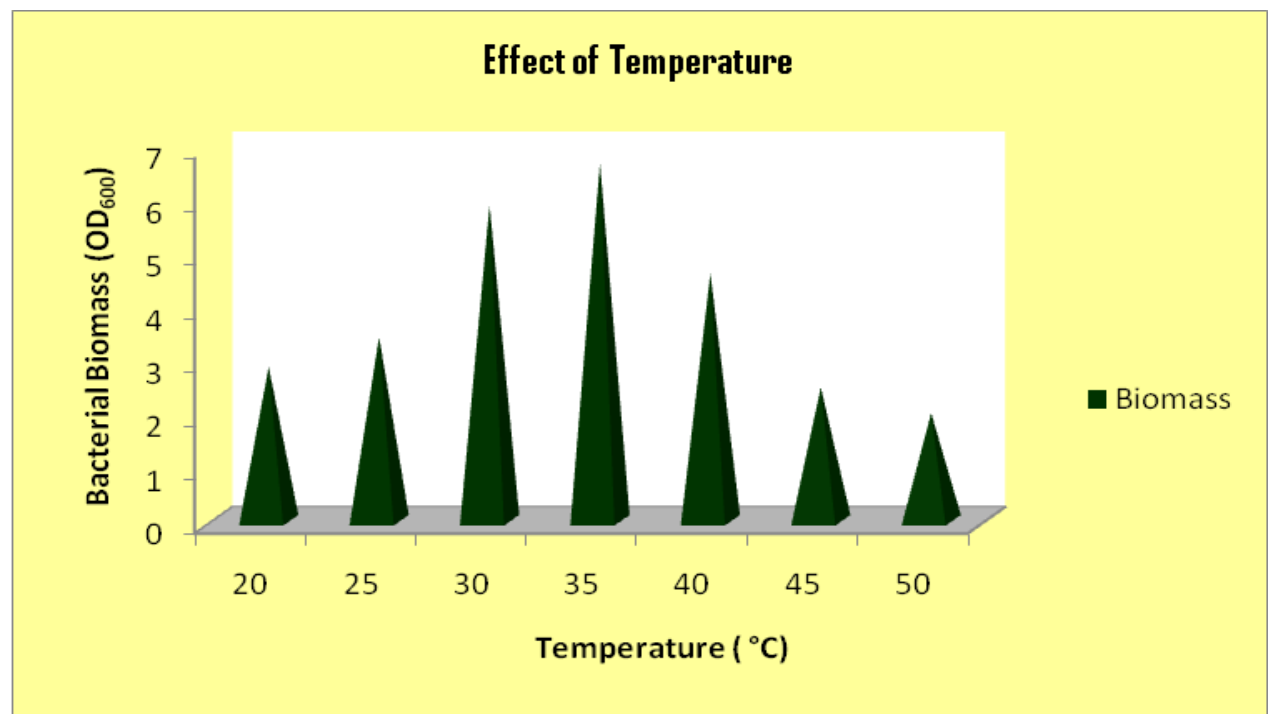

Fig.5 Effect of $\mathrm{pH}$ on the biomass of Staphylococcus aureus strain BRTSI-1

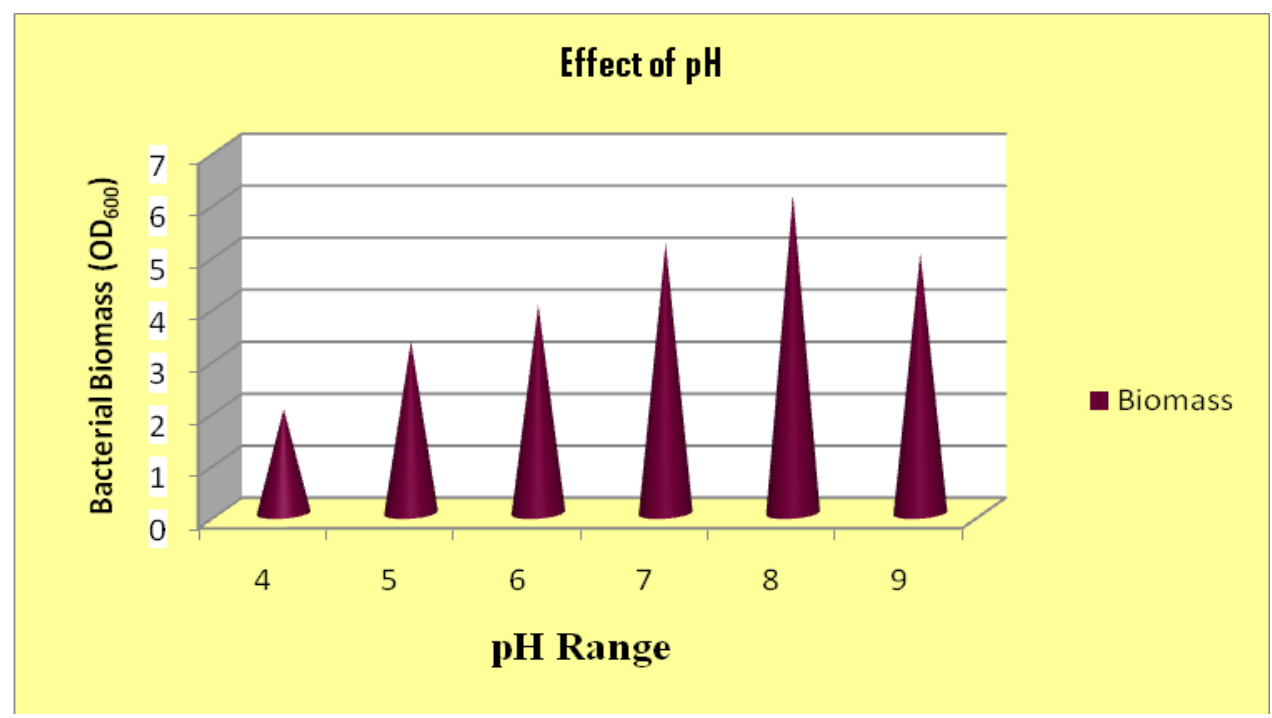


Fig.6 UV Vis spectra of methanolic extract of BRTSI-1 carotenoid pigment

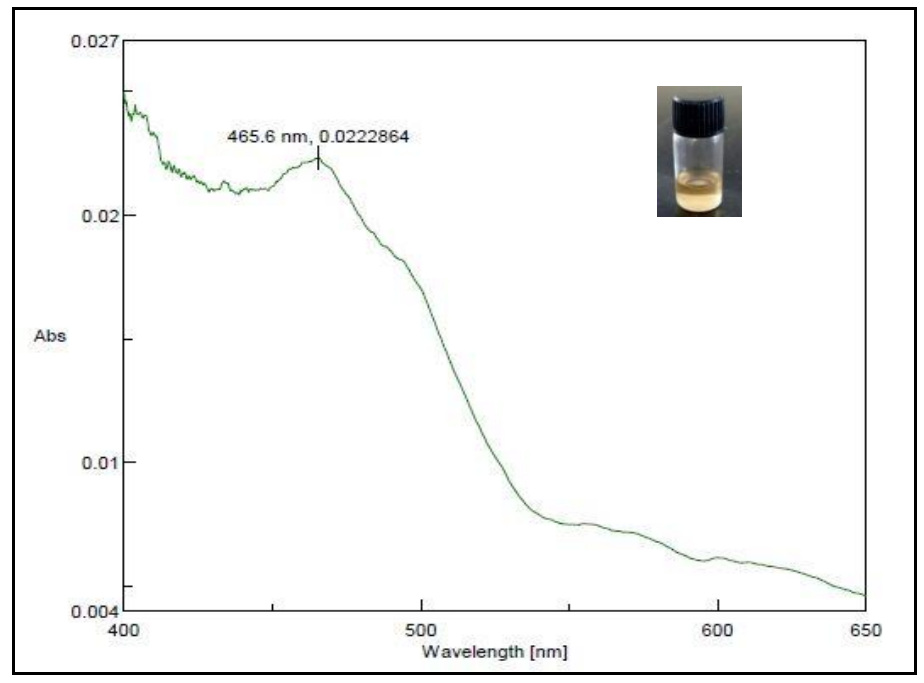

Fig.7 FTIR spectra of methanolic extract of BRTSI-1 carotenoid pigment

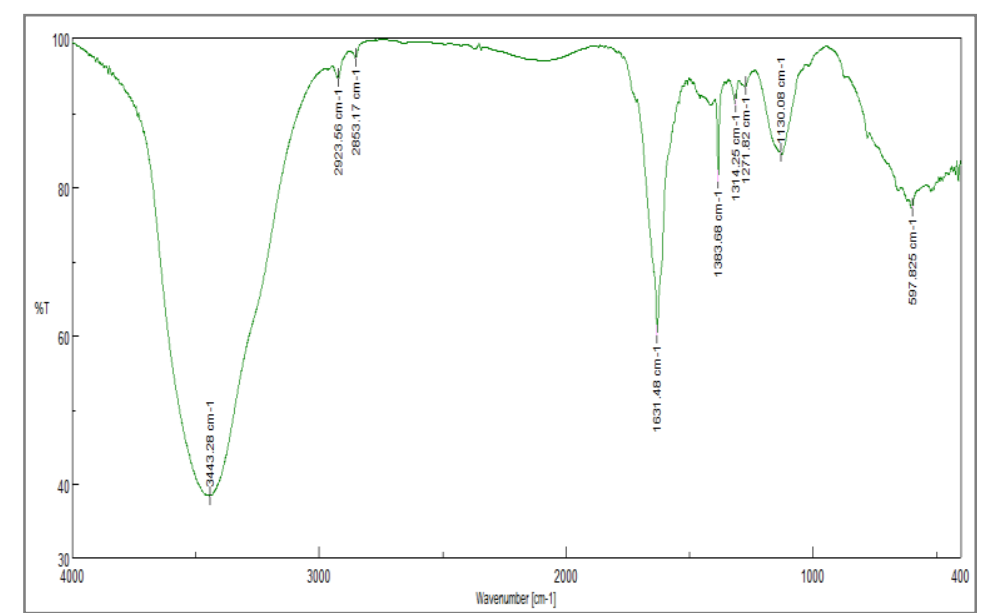

The methanolic extract of the bacterial pigment obtained from the bacterial pellet of Staphylococcus aureus strain BRTSI-1 was found to have a sharp peak at $465 \mathrm{~nm}$ in UVVIS spectrophotometry, which confirms the presence of carotenoids. The spectrum was observed between 400 to $650 \mathrm{~nm}$ (Fig. 6).

\section{FTIR analysis of bacterial carotenoid}

One of the main identification tests for pigment is IR spectrum. Pigment exhibited bright spectral absorption of lines, $3443 \mathrm{~cm}^{-1}$ which showed the presence of hydroxyl group
$(\mathrm{OH})$ that attributed to the $\mathrm{O}-\mathrm{H}$ bending peaks or secondary amine group $\mathrm{N}=\mathrm{N}$. Peak at $2923 \mathrm{~cm}^{-1}$ and $2853 \mathrm{~cm}^{-1}$ indicated the presence of amine group. Sharp peak at 1631 $\mathrm{cm}^{-1}$ represented the presence of carbonyl group (RCOR) which comes under carboxylic acids. Vibrations near $1383 \mathrm{~cm}^{-1}$ indicated the presence of alkanes and alkyl class of compounds. The spectra near $1314 \mathrm{~cm}^{-1}$ indicated the presence of alkyl halides (R-F).

In this study, chromogenic bacterial strain BRTSI-1was isolated from Rhizosphere. Further it was subjected to biochemical 
analysis and $16 \mathrm{~S}$ rDNA molecular sequencing which revealed that the BRTSI-1 as Staphylococcus aureus. The strain BRTSI-1 was submitted to NCBI with accession number MH412806. Bacterial growth and pigment production was found to be optimized at $\mathrm{pH} 7.0$ at $35^{\circ} \mathrm{C}$. These carotenoids pigments may play an important role in providing protection against photooxidative damage. Carotenoids can be explored to prevent cancer and reduce the risk of cardiovascular and Alzheimer disease due to their antioxidative properties.

\section{References}

Choi, A., Chung, E.J., Nam, Y.H., Choi, G., 2017. Genome sequence of carotenoid producing Sphingobacteriaceae bacterium $\mathrm{SH}-48$ isolated from freshwater in Korea. Korean J. Microbiol. 53, 347-350.

Garg, N., Ram, R.A., 2017. Microbial properties of pigmented bacteria isolated from bioenhancer "Amrit pani." Indian J. Tradit. Knowl. 16, 669-673.

Kirsh VA, Mayne ST, Peters U, Chatterjee N, Leitzmann MF, Dixon LB, U., DA, Crawford ED, H.R., 2006. A prospective study of lycopene and tomato product intake and risk of prostate cancer. Cancer Epidemiol Biomarkers 15, 92-98.

Kumar, A., Vishwakarma, H.S., Singh, J., Kumar, M., 2015. Microbial pigments: production and their applications in various industries. Int. J. Pharm. Chem. Biol. Sci. 5, 203-212.

Luiza, T., Grigoletto, B., Alberto, L., Moraes, B. De, Abreu, L.M., Santos, C., Galva, L.R., 2018. Production and chemical characterization of pigments in filamentous fungi. Microbiology 162 , $12-22$.

https://doi.org/10.1099/mic.0.000168.

Prasad, M.P., Swaroop, J.K., Baral, M., Sayeed, N., P, S.K.A., 2013. Optimization of physico-chemical parameters for pigment production in bacteria isolated from different effluent water samples. Int. Res. J. Pharm. Appl. Sci. 3, 27-30.

Ribeiro, C.M., Jurandy, E., Nogueira, B., 2012. Isolation, selection and characterization of root-associated growth promoting bacteria in Brazil Pine (Araucaria angustifolia). Microbiol. Res. 167, 69-78. https://doi.org/10.1016/ J.Mic. Res. 2011.03.003.

Smitha, K., Nath, S.S., April, M., April, M., 2017. Activity of novel yellow pigment produced by Micrococcus yunnanensis S- CSR-0010 against multidrug resistant Staphylococcus aureus. Res. J. Pharm. Biol. Chem. Sci. 8, 715-722.

Valero, A., Pérez-rodríguez, F., Carrasco, E., Fuentes-alventosa, J.M., Garcíagimeno, R.M., Zurera, G., 2009. Modelling the growth boundaries of Staphylococcus aureus: Effect of temperature, $\mathrm{pH}$ and water activity. Int. J. Food Microbiol. 133, 186-194.

\section{How to cite this article:}

Suwetha P., S. Shivaranjani, M. Soundarya, B. Santhiya, V. Roja, N. Aaliya Mehnaaz, G. Vaishnavi, G. Ramya, A. Vidya, A. Barathi and Hemapriya J. 2018. Exploration of Rhizosphere Associated Chromogenic Bacterial Strain - Staphylococcus aureus Strain BRTSI1. Int.J.Curr.Microbiol.App.Sci. 7(08): 4374-4380. doi: https://doi.org/10.20546/ijcmas.2018.707.510 